\title{
ASUHAN KEBIDANAN PADA BAYI BARU LAHIR DENGAN IKTERUS FISIOLOGIS DI PMB DINCE SAFRINA TAHUN 2020
}

\author{
Kiki Megasari \\ STIKes Hang Tuah Pekanbaru
}

\begin{abstract}
Jaundice is the yellow coloration of the skin, conjunctiva, and mucosa that occurs due to increased levels of bilirubin in the blood. Jaundice begins to appear when the serum bilirubin level is $\geq 5 \mathrm{mg} /$ $d l$ and starts in the facial area. IMR data in the World in 2012 amounted to 49 per 1000 live births, High Risk Infant or baby factors that increase the risk of perinatal or neonatal mortality, one of which is Neonatal Jaundice or Jaundice which is the cause of neonatal death in about 20-40\% of all deliveries. The objective of the case study is to be able to carry out midwifery care in mothers of newborns with physiological jaundice. The method used with the midwifery management approach is then documented in the form of SOAP recording and care for the baby how long the icterus will disappear after drying the baby for about 15 minutes in the morning sun and giving adequate breast milk. The case study was conducted at PMB Hj. Dince Safrina and continued at the patient's home from 27 August - 02 September 2020. From the results of the Midwifery Care that was carried out during 4 home visits to babies with physiological jaundice, in the end, Ikerus in babies was resolved, by drying the baby every day in the morning sun. without wearing clothes and giving adequate breast milk. It is hoped that health facilities can encourage post-partum mothers to be able to breastfeed their babies adequately and advise mothers to be able to expose their babies to the morning sun so that the baby does not develop jaundice.
\end{abstract}

\section{Keywords: Midwifery Care, Physiological Jaundice}

\begin{abstract}
ABSTRAK
Ikterus adalah warna kuning di kulit, konjungtiva, dan mukosa yang terjadi karena peningkatan kadar bilirubin dalam darah. Ikterus mulai tampak jika kadar bilirubin dalam serum $\geq 5$ $\mathrm{mg} / \mathrm{dl}$ dan dimulai pada daerah wajah. Data AKB di Dunia tahun 2012 sebesar 49 per 1000 kelahiran hidup, High Risk Infant atau faktor bayi yang mempertinggi risiko kematian perinatal atau neonatal tersebut salah satunya adalah Ikterus Neonatorum atau Ikterus yang merupakan penyebab kematian neonatal sekitar 20-40\% dari seluruh persalinan. Tujuan Studi kasus adalah mampu melaksanakan asuhan kebidanan pada ibu bayi baru lahir dengan Ikterus Fisiologis. Metode yang digunkan dengan pendekatan manajemen kebidanan kemudian didokumentasikan dalam bentuk pencatatan SOAP serta dilakukan asuhan terhadap bayi seberapa lama icterus akan menghilang setelah dilakukan menjemur bayi selam lebih kurang 15 menit dibawah sinar matahari pagi dan memberi ASI dengan adekuat. Studi kasus dilaksanakan di PMB Hj. Dince Safrina dan dilanjutkan di rumah pasien dari tanggal 27 Agustus - 02 September 2020. Dari hasil Asuhan Kebidanan yang dilakukan selama 4 kali kunjungan rumah terhadap bayi dengan Ikterus Fisiologis, pada akhirnya Ikerus pada bayi teratasi, dengan cara menjemur bayi setiap hari dibawah sinar matahari pagi tanpa menggunakan pakaian serta memberi ASI secara adekuat. Diharapkan kepada tempat fasilitas kesehatan untuk dapat menyemangati ibu nifas agar dapat memberi ASI pada bayinya dengan adekuat serta menyarankan ibu untuk dapat menjemur bayinya dibawah sinar matahari pagi agar tidak terjadi kuning pada bayi.
\end{abstract}

\section{Kata Kunci : Asuhan Kebidanan, Ikterus Fisiologi}




\section{PENDAHULUAN}

Ikterus adalah warna kuning di kulit, konjungtiva, dan mukosa yang terjadi karena peningkatan kadar bilirubin dalam darah. Ikterus mulai tampak jika kadar bilirubin dalam serum $\geq 5 \mathrm{mg} / \mathrm{dl}$ dan dimulai pada daerah wajah (Tando, 2018).

Menurut pratama (2013) dalam (Puspita, 2018), Ikterus itu terbagi atas dua jenis, yaitu fisiologis dan patologis. IkterusFisiologis merupakan ikterus yang sering terdapat pada bayi dengan bobot berat badan lahir rendah. Ikterus biasanya terlihat pada hari kedua lalu tidak terlihat lagi setelah sepuluh hari atau saat terakhir minggu kedua. Ikterus fisiologis dalam keadaan normal, kadar bilirubin indirek dalam serum tali pusat adalah 1-3 mg/dl dan akan meningkat dengan kecepatan kurang dari $5 \mathrm{mg} / \mathrm{dl}$ 124 jam, dengan demikian ikterus baru terlihat pada hari ke 2-3, biasanya mencapai puncak antara hari ke 2-4, dengan kadar 5-6 mg/dl untuk selanjutnya menurun sampai kadar 5-6 $\mathrm{mg} / \mathrm{dl}$ untuk selanjutnya menurun sampai kadarnya lebih rendah dari 2 $\mathrm{mg} / \mathrm{dl}$ antara hari ke 5-7 kehidupan.

Data dari World Health Organization (WHO) tahun 2012 menyebutkan bahwa AKB di Dunia tahun 2012 sebesar 49 per 1000 kelahiran hidup, High Risk Infant atau faktor bayi yang mempertinggi risiko kematian perinatal atau neonatal tersebut salah satunya adalah ikterus neonatorum atau ikterus yang merupakan penyebab kematian neonatal sekitar $20-40 \%$ dari seluruh persalinan (Widiyant, 2017).

Angka kejadian ikterus Neonatorum di dunia yang cukup tinggi terjadi di Amerika Serikat, dari 4 juta neonatus yang lahir setiap tahunnya sekitar $65 \%$ menderita ikterus dalam minggu pertama kehidupannya (Rafi \& Nopiyanti, 2016) Sedangkan di Indonesia pada tahun 2009 proporsi ikterus neonatorum pada bayi cukup bulan berjumlah $32,1 \%$ dan pada bayi kurang bulan sebesar 42,9\% (S. Lestari, 2017).

Untuk jumlah kejadian ikterus di Kota Pekanbaru, yang diperoleh dari RSUD Arifin Achmad Provinsi Riau sebagai rumah sakit rujukan Provinsi Riau berdasarkan hasil penelitian (Febrianti, 2017) tentang Faktor-Faktor Penyebab Terjadinya Ikterus pada Neonatorum di ruangan NICU di RSUD Arifin Achmad Provinsi Riau Tahun 2016, berjumlah 46 kasus dengan distribusi frekuensi BBLR yang menyebabkan Ikterus yaitu sebanyak 26 orang $(56,5 \%)$, pada bayi baru lahir Prematur sebanyak 18 orang 
(31,1\%),dan pada bayi yang kurang ASI

yaitu sebanyak2 orang (4,4\%).

Berdasarkan hasil penelitian (Azizah,

2018) tentang Faktor-Faktor yang

Berhubungan dengan Kejadian Ikterus

Neonatorum di Ruang Perina RSUD

Arifin Achmad Provinsi Riau Tahun

2017 menyebutkan bahwa angka

kejadian Ikterus Neonatorumdi RSUD

Arifin Achmad Provinsi Riau tahun

2017 adalahsebanyak 118 kasus

$(17,6 \%)$. Hal ini membuktikan bahwa

terjadi peningkatan kasus Ikterus

Neonatorum dari tahun sebelumnya.

Oleh karena itu, perlu kiranya dilakukan asuhan kebidanan yang menyeluruh agar kasus tersebut tidak bertambah setiap tahunnya.

Salah satu penyebab terjadinya Ikterus fisiologis pada bayi adalah karena pemberian minum atau ASI yang belum mencukupi. Bayi yang puasa panjang atau asupan kalori/cairan yang belum mencukupi akan menurunkan kemampuan hati untuk memperoses bilirubin. Sebagian bahan yang terkandung dalam ASI (beta glucuronidase) akan memerah bilirubin menjadi bentuk yang larut dalam lemak, sehingga bilirubin indirek akan meningkat, dan kemudian akan diresorbsi oleh usus. Frekuensi fases yang jarang pada bayi yang minum ASI kemungkinan disebabkan karena usus memerlukan waktu yang lebih panjang untuk meresorbsi bilirubin (Ambarwati \& Nasution, 2012).

Selain menyusui bayi secara teratur, untuk mengatasi terjadinya ikterus bayi juga dapat di jemur dibawah sinar matahari pagi selama 1015 menit setiap hari hingga ikterusnya menghilang (Klien et al., 2015).

Sehingga sinar matahari direkomendasikan sebagai salah satu alternatif mengatasi ikterus. Bayi dianjurkan dijemur sinar matahari antara pukul 7-8 pagi (Tando, 2018).

\section{METODE}

Dalam metode ini menggunakan studi kasus, studi kasus yaitu metode kasus yang dilakukan dengan cara meneliti suatu pemersalahan melalui suatu kasus yang terdiri dari unit tunggal. Metode ini digunakan dalam bentuk pengkajian data subjektif, objektif, assesment dan penatalaksanaan. Metode ini menggali tentang bagaimana asuhan yang benar pada bayi baru lahir dengan ikterus fisiologis.Dalam metode ini menggunakan studi kasus, studi kasus yaitu metode kasus yang dilakukan dengan cara meneliti suatu pemersalahan melalui suatu kasus yang terdiri dari unit tunggal. Metode ini digunakan dalam bentuk pengkajian data subjektif, objektif, assesment dan 
penatalaksanaan. Metode ini menggali tentang bagaimana asuhan yang benar pada bayi baru lahir dengan ikterus fisiologis. Dalam metode ini menggunakan studi kasus, studi kasus yaitu metode kasus yang dilakukan dengan cara meneliti suatu pemersalahan melalui suatu kasus yang terdiri dari unit tunggal. Metode ini digunakan dalam bentuk pengkajian data subjektif, objektif, assesment dan penatalaksanaan. Metode ini menggali tentang bagaimana asuhan yang benar pada bayi baru lahir dengan ikterus fisiologis. Pengambilan kasus dilakukan pada tanggal 27 Agustus- 02 September 2020. Pengambilan kasus dilakukan dengan mendatangi PMB $\mathrm{Hj}$. Dince Safrina, SST dan disana menemukan klien,dan kemudian menjelaskan kepada klien apa yang akan dilakukan terhadap bayinya. Penulis akan memberikan Asuhan Kebidanan pada Bayi Baru Lahir dengan Ikterus Fisiologis. Diharapkan ibu bayi setuju dengan kesepakatan yang telah dibuat.

\section{HASIL}

Kunjungan pertama dilakukan pada hari Kamis, Tanggal 27 Agustus 2020 pukul 16.00 WIB di Jl. Limbungan gang Abadi no.3.

1. Data Subjektif
Ibu merasa bahagia anak pertamanya telah lahir dengan persalinan normal, sebelumnya ibu tidak pernah keguguran. Bayinya lahir tanggal 23 Agustus 2020 pukul 22.30 wib dengan BB bayi 3.300 gr, PB bayi $50 \mathrm{~cm}$ dan jenis kelamin perempuan.

Ibu mengatakan khawatir kulit bayinya bewarna kuning

Ibu mengatakan bayinya tidur terus sehingga sulit untuk menyusu setiap 2 jam sekali, hanya 4-5 x sehari.

Ibu mengatakan bayinya hanya diberi ASI saja.

Ibu mengatakan tidak ada riwayat minum obat-obatan dan jamu.

\section{Data Objektif}

Keadaan umum bayi baik, Kesadaran composmentis, JK Perempuan, BB 3400 gram, PB $48 \mathrm{~cm}, \mathrm{~S} 36,7{ }^{\circ} \mathrm{C}, \mathrm{N}$ 125 x/i, P 40 x/i, Tali pusat sudah lepas, Kulit tampak kuning pada bagian muka dan abdomen, Kadar bilirubin tidak lebih dari $9.0 \mathrm{mg} \%$.

3. Analisa

Neonatus cukup bulan, umur 4 hari dengan Ikterus Fisiologis

4. Penatalaksanaan

1. Informasikan hasil pemeriksaan

Keadaan umum bayi baik, Kesadaran composmentis, JK Perempuan, BB 3400 gram, PB $48 \mathrm{~cm}, \mathrm{~S} 36,7^{\circ} \mathrm{C}, \mathrm{N}$ 
125 x/i, P 40 x/i, Tali pusat sudah lepas, Kulit tampak kuning pada bagian muka dan abdomen, Kadar bilirubin tidak lebih dari $9.0 \mathrm{mg} \%$.

2. Berikan Pendidikan Kesehatan (Pendkes) kepada klien tentang ikterus fisiologis. Jelaskan kepada ibu bahwa kuning pada bayi termasuk hal yang normal pada bayi, karena timbul pada hari ketiga atau hari keempat dan akan menghilang setelah sepuluh hari atau saat terakhir minggu kedua.

3. Berikan Pendidikan Kesehatan (Pendkes) kepada klien tentang cara membangunkan bayi saat tidur Gendong bayi dengan posisi tegak, usap-usap pipi dan sekitar bibir bayi, merangsang/ menyentil kaki bayi.

4. Ajarkan ibu teknik menyusui

a. Anjurkan ibu untuk mencuci tangan sebelum dan sesudah menyusui

b. Keluarkan ASI sedikit dan dioleskan pada puting dan disekitar areola payudara

c. Atur posisi menyusui

1) Posisi menyusui sambil duduk yang benar, sangga punggung ibu dengan bantal, letakkan batal di paha ibu tempat meletakkan bayi
2) Posisikan bayi menghadap dada ibu, mulut tepat didepan putting susu ibu

3) Beri rangsangan agar bayi membuka mulut, dengan cara menyentuh pipi bayi dengan puting dan menyentuh mulut bayi

5. Berikan Pendkes kepada klien tentang Pemenuhan ASI ekslusif pada bayi. Anjurkan pada ibu untuk memberikan ASI ekslusif selama 6 bulan tanpa Mp ASI, menganjurkan ibu menyusui bayinya minimal 2 jam sekali atau tanpa batasan.

6. Berikan Pendkes kepada klien tentang tanda bahaya pada BBL. Beritahu ibu tanda bahaya pada bayi seperti demam, tidak mau menyusui, nafas lebih cepat, hiportermi, mengantuk terus, tali pusat berdarah atau berbau

7. Berikan Pendkes pada klien tentang cara menangani ikterus fisiologis pada bayi Menjemur bayi di bawah sinar matahari pagi pukul 07.0008.00 wib selama 5-10 menit dengan cara membuka seluruh pakaian bayi kecuali alat vital, dan menutup bagian mata. Selanjutnya merubah posisi bayi agar sinar matahari dapat merata keseluruh tubuh. Sinar matahari merupakan tindakan 
pencegahan untuk mengantisipasi terjadinya penimbunan bilirubin dalam darah yan berlebihan dan sinar matahari juga baik untuk penumbuhan tulang pada bayi karena terdapat Vit D pada sinar matahari.

8. Kunjungan rumah kembali pada tanggal 28 Agustus 2020

\section{PEMBAHASAN}

Data subjektif yang ditemukan pada kajian 1 yaitu ibu mengatakan bahwa khawatir dengan kondisi kulit bayinya yang berwarna kuning yang muncul pada hari ke-3 setelah bayi lahir. Setelah dilakukan pemeriksaan, ditemukan data objektif bahwa terjadi warna kuning pada kulit bayi, konjungtiva dan mukosa. Tanda vital dalam batas normal, Berat Badan 3300 gram, reflek menghisap dan menelan kuat dan gerakan kurang aktif. Hal ini selaras dengan teori yang ditemukan yang sisadur dari Tando (2018) yang menyebutkan bahwa Ikterus adalah warna kuning di kulit, konjungtiva dan mukosa yang terjadi karena meningkatnya kadar bilirubin dalam darah. Ditambah lagi dengan teori yang di sadur dari Dewi (2010) yang memaparkan bahwa Ikterus fisiologis adalah ikterus yang timbul pada hari kedua dan hari ke tiga serta tidak mempunyai dasar patologis atau tidak mempunyai potensi menjadi kern ikterus.
Kadar bilirubin inderek tidak melebihi 10 mg\% pada neonatus kurang bulan dan akan hilang paling lama pada hari ke-14. Untuk asuhan kebidanan bayi dengan Ikterus fisiologis selanjutnya penulis memberikan asuhan dengan menganjurkan ibu untuk menjemur bayinya dibawah sinar matahari pagi pada pukul 07.00 pagi atau pukul 08.00 pagi minimal selama 5-10 menit. Hal ini selaras dengan teori yang disadur dari (Sudarmoko, 2011) yang memaparkan bahwa penanganan bayi dengan Ikterus Fisiologis adalah selain membantu ibu dan bayi menyusu secara teratur juga dengan menjemur bayi dibawah sinar matahari pagi karena sinar matahari pagi membantu memecah bilirubin. Dilakukan selama 5-10 menit karena pancaran matahari yang terlalu lama akan menyebabkan terbakarnya kulit bayi. Menjemur bayi ini dilakukan dengan cara membuka seluruh pakaian bayi kecuali alat vital biarkan saja tertutup popok bayi dan menutup bagian mata. Selanjutnya merubah posisi bayi agar sinar matahari dapat merata ke seluruh tubuh.

\section{KESIMPULAN}

Setelah dilakukan pengkajian sampai evaluasi kasus tidak terdapat kesenjangan antara teori dan praktik di lapangan. 


\section{SARAN}

\section{PMB Hj. Dince Safrina, S.ST}

Diharapkan kepada PMB untuk dapat meningkatkan pelayanan kesehatannya terutama pada pelayanan kebidanan pada bayi baru lahir untuk dapat mendeteksi secara dini tanda-tanda bahaya pada bayi baru lahir dan terkhusus pada asuhan yang dilakukaan saat ini diharapkan tenaga Kesehatan pada PMB dapat memberikan Pendidikan Kesehatan kepada ibu nifas dan keluarganya untuk dapat selalu memberikan ASI kepada bayi baru lahirnya dengan adekuat dan menjemur bayinya setiap hari dibawah sinar matahari pagi selama 15-30 menit apabila terindikasi si bayi mengalami ikterus fisiologis. Disamping itu juga diharapkan tenaga Kesehatan tersebut dapat membantu si ibu untuk melakukan asuhan terhadap bayinya dengan ikterus fisiologis agar kondisi si bayi kembali normal.

2. STIKes Hang Tuah Pekanbaru

Diharapkan studi kasus yang telah dilakukan dapat menambah sumber wawasan pengetahuan mahasiswa DIII Kebidanan STIKes Hang Tuah Pekanabaru serta dijadikan sebagai referensi sebagai pengembangan ilmu pengetahuan tentang asuhan kebidanan pada bayi baru lahir dan menjadi pedoman untuk studi kasus berikutnya.

3. Bagi Mahasiswa

a. Diharapkan studi kasus ini dapat dijadikan pedoman atau informasi dan menambah pengetahuan penulis selanjutnya yang akan melakukan studi kasus yang serupa.

b. Perlunya dilaksanakan pelayanan asuhan kebidanan pada bayi baru lahir agar dapat mendeteksi secara dini tanda tanda bahaya pada bayi baru lahir dan agar dapat segera teratasi permasalahan yang ada dengan melakukan asuhan kebidanan pada bayi baru lahir tersebut

\section{DAFTAR PUSTAKA}

Ambarwati, F. R., \& Nasution, N. (2012). BUKU PINTAR ASUHAN KEPERAWATAN BAYI \& BALITA. Yogyakarta

Azizah. (2018). Faktor-faktor yang berhubungan dengan kejadian ikterus Neonatorum di ruang Perina RSUD Arifin Achmad Provisi Riau Tahun 2017.

Febrianti. (2017). Faktor-fakyor penyebab terjainya ikterus pada neonatorum di ruangan NICU di RSUD Arifn Achmad Provinsi Riau tahun 2016. 78-82.

IKlien, S., Miller, S., \& Thomson, F. 
(2015). Buku Bidan Asuhan pada

Kehamilan, Kelahiran \& Kesehatan Wanita.

Lestari, S. (2017). hubungan berat badan lahir bayi dan usia kehamilan dengan kejadian ikterus Neonatorum di RSUD sleman tahun 2017,Politeknik kesehatan kementrian kesehatan.

Puspita, N. (2018). Pengaruh berat badan lahir rendah terhadap kejadian ikterus neonatorum di sidoarjo. 6(December 2013), 174181.

https://doi.org/10.20473/jbe.v6i2201 8.174-181

Rafi, R., \& Nopiyanti, A. (2016). Pengaruh berat badan lahir rendah terhadap ikterus neonatorum pada neonatus di ruang perinatologi rsud karawang provinsi jawa barat tahun 2016. 4, 12-17.
Tando, N. M. (2018). ASUHAN KEBIDANAN Neonatus, Bayi, \& Anak Balita.

Widiyant, S. (2017). Juni 2017 Hubungan sepsis neonatorum , BBLR dan asfiksia dengan kejadian ikterus pada bayi baru lahir Susi Widiawati Abstrak PENDAHULUAN Masalah yang sering dialami oleh bayi baru lahir adalah Ikterus neonatorum yaitu pewarnaan kuning yang tampak pada skl. 6(1).

Tumbu Sehat. Pustaka Baru Press.

Wiji, R. N. (2013). ASI Dan Pedoman Ibu Penyusui. Nuha Medika. 